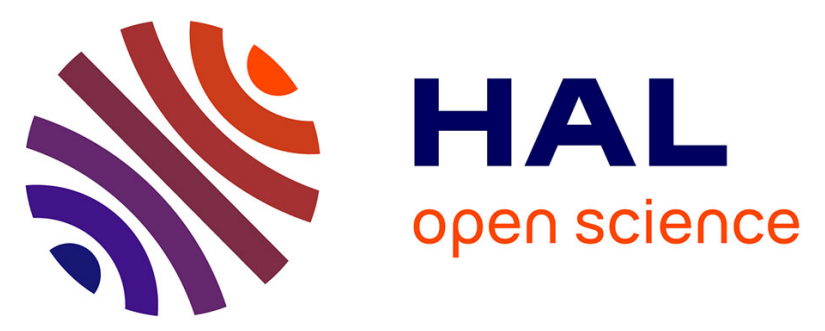

\title{
Mid-Infrared Laser Emissions of Tm 3+ -doped Garnets: The Case Study of Disordered Tm:CNGG Crystal
}

\author{
Lauren Guillemot, Pavel Loiko, Zhongben Pan, Jean-Louis Doualan, Alain \\ Braud, Patrice Camy
}

\section{- To cite this version:}

Lauren Guillemot, Pavel Loiko, Zhongben Pan, Jean-Louis Doualan, Alain Braud, et al.. MidInfrared Laser Emissions of Tm 3+ -doped Garnets: The Case Study of Disordered Tm:CNGG Crystal. 2021 Conference on Lasers and Electro-Optics Europe \& European Quantum Electronics Conference (CLEO/Europe-EQEC), Jun 2021, Munich, Germany. pp.1-1, 10.1109/CLEO/EuropeEQEC52157.2021.9542032 . hal-03368296

\section{HAL Id: hal-03368296 https://hal.science/hal-03368296}

Submitted on 7 Oct 2021

HAL is a multi-disciplinary open access archive for the deposit and dissemination of scientific research documents, whether they are published or not. The documents may come from teaching and research institutions in France or abroad, or from public or private research centers.
L'archive ouverte pluridisciplinaire HAL, est destinée au dépôt et à la diffusion de documents scientifiques de niveau recherche, publiés ou non, émanant des établissements d'enseignement et de recherche français ou étrangers, des laboratoires publics ou privés. 


\title{
Mid-Infrared Laser Emissions of $\mathrm{Tm}^{3+}$-doped Garnets: The Case Study of Disordered Tm:CNGG Crystal
}

\author{
Lauren Guillemot ${ }^{1, *}$, Pavel Loiko ${ }^{1}$, Zhongben Pan ${ }^{2}$, Jean-Louis Doualan ${ }^{1}$, Alain Braud ${ }^{1}$, and Patrice Camy ${ }^{1}$ \\ 1. Centre de Recherche sur les Ions, les Matériaux et la Photonique (CIMAP), UMR 6252 CEA-CNRS-ENSICAEN, Université de Caen \\ Normandie, 6 Boulevard du Maréchal Juin, 14050 Caen Cedex 4, France.E-mail: lauren.guillemot@ensicaen.fr \\ 2. Institute of Chemical Materials, China Academy of Engineering Physics, Mianyang, 621900, China
}

Recently, disordered garnets such as CNGG (calcium niobium gallium garnet) doped with $\mathrm{Tm}^{3+}$ and codoped with $\mathrm{Tm}^{3+}$ and $\mathrm{Ho}^{3+}$ ions have attracted a lot of attention for generation of ultrashort pulses at $\sim 2 \mu \mathrm{m}$ [1]. Pan et al. reported on a Tm oscillator operating on the ${ }^{3} \mathrm{~F}_{4} \rightarrow{ }^{3} \mathrm{H}_{6}$ transition and delivering 84 fs pulses at $2018 \mathrm{~nm}$ (emission bandwidth: $>50 \mathrm{~nm}$ ) and demonstrated continuous wavelength tuning between 1879-2086 nm [1]. It is interesting to extend the emission range of such crystals further into mid-IR. It can be done by exploiting either (i) vibronic emissions relying on electron-phonon-coupling or (ii) less common electronic ${ }^{3} \mathrm{H}_{4} \rightarrow{ }^{3} \mathrm{H}_{5}$ transition [2].

A 3.2 at.\% Tm:CNGG crystal was grown by the Czochralski method. The stimulated-emission (SE) crosssection, $\sigma \mathrm{SE}$, spectra for its near- and mid-IR emissions were determined using the Füchtbauer-Ladenburg equation with the radiative lifetimes $\tau_{\mathrm{rad}}$ and branching ratios $\beta_{\mathrm{JJ}}$ calculated using the Judd-Ofelt formalism, Fig. 1(a). For the ${ }^{3} \mathrm{~F}_{4} \rightarrow{ }^{3} \mathrm{H}_{6}$ transition, $\sigma \mathrm{SE}=0.44 \times 10^{-20} \mathrm{~cm}^{2}$ at $1865 \mathrm{~nm}$ and the emission extends until $2.2 \mu \mathrm{m}$ owing to a phonon sideband. For the ${ }^{3} \mathrm{H}_{4} \rightarrow{ }^{3} \mathrm{H}_{5}$ transition, $\sigma_{\mathrm{SE}}=0.28 \times 10^{-20} \mathrm{~cm}^{2}$ at $2331 \mathrm{~nm}$ (emission bandwidth: $132 \mathrm{~nm}$ ). The gap between these electronic transitions is bridged by vibronic processes. The reabsorption-free luminescence lifetimes $\tau_{\text {lum }}\left({ }^{3} \mathrm{~F}_{4}\right)=3.26 \mathrm{~ms}$ and $\left\langle\tau_{\text {lum }}\left({ }^{3} \mathrm{H}_{4}\right)\right\rangle=0.181 \mathrm{~ms}$, Fig. $1(\mathrm{~b})$.
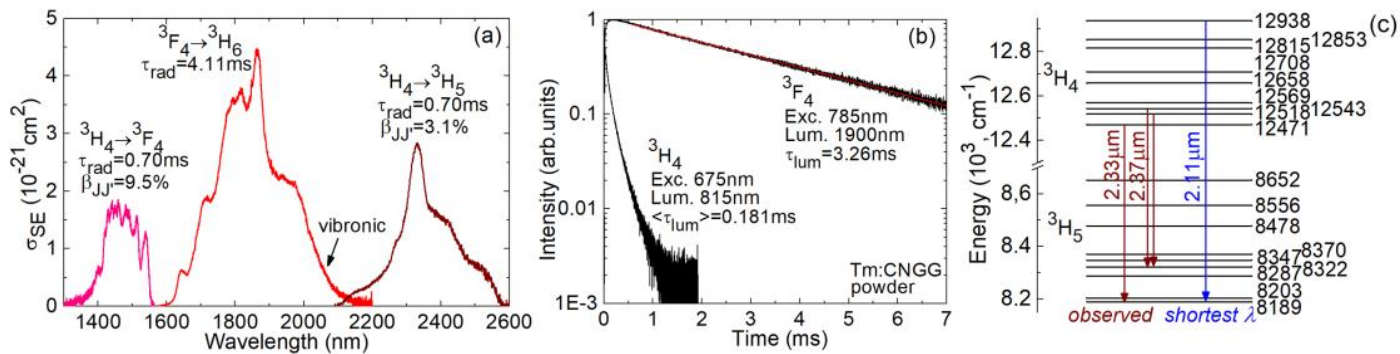

Fig. 1 Spectroscopy of 3.2 at $\%$ Tm:CNGG crystal: (a) Stimulated-emission (SE) cross-sections, $\sigma_{\mathrm{SE}}$, for (from left to right) the ${ }^{3} \mathrm{H}_{4}$ $\rightarrow{ }^{3} \mathrm{~F}_{4},{ }^{3} \mathrm{~F}_{4} \rightarrow{ }^{3} \mathrm{H}_{6}$ and ${ }^{3} \mathrm{H}_{4} \rightarrow{ }^{3} \mathrm{H}_{5} \mathrm{Tm}^{3+}$ transitions; (b) RT luminescence decay curves from the ${ }^{3} \mathrm{H}_{4}$ and ${ }^{3} \mathrm{~F}_{4}$ states; (c) crystal-field splitting of the ${ }^{3} \mathrm{~F}_{4}$ and ${ }^{3} \mathrm{H}_{4}$ multiplets (revealed at $12 \mathrm{~K}$ ).

The laser experiments were performed using an [111]-cut uncoated Tm:CNGG sample (thickness: $6.0 \mathrm{~mm}$ ). A hemispherical cavity was formed by a flat pump mirror coated for HT at $\sim 0.79 \mu \mathrm{m}$ and for HR at 1.90-2.35 $\mu \mathrm{m}$ and several concave output couplers (OCs) $(\mathrm{RoC}=-100 \mathrm{~mm})$. We used one "conventional" non-selective OC (\#1) and two special "shortpass" OCs (\#2 and \#3) designed to force the laser oscillations above $2 \mu \mathrm{m}$, Fig. 2(a). The pump source was a Ti:Sapphire laser tuned to $785.8 \mathrm{~nm}$. Two types of emission were detected: (i) a purely electronic ${ }^{3} \mathrm{~F}_{4}$ $\rightarrow{ }^{3} \mathrm{H}_{6}$ one using OC \#1 (maximum power: $500 \mathrm{~mW}$ at $1.99 \mu \mathrm{m}$ with a slope efficiency $\eta$ of $26.1 \%$ ), and (ii) a mixture of vibronic emission at 2.08 or $2.13 \mu \mathrm{m}$ and a purely electronic ${ }^{3} \mathrm{H}_{4} \rightarrow{ }^{3} \mathrm{H}_{5}$ one at 2.33 or $2.37 \mu \mathrm{m}$ using OCs \#2 and \#3 (maximum power: $548 \mathrm{~mW}$ with a total $\eta=58.2 \%$ ), Fig. 2(b,c). The observed laser lines agreed with the crystalfield splitting of the corresponding multiplets determined at $12 \mathrm{~K}$, Fig. 1(c). The weaker contribution of the ${ }^{3} \mathrm{H}_{4} \rightarrow$ ${ }^{3} \mathrm{H}_{5}$ emission is assigned to strong self-quenching of the ${ }^{3} \mathrm{H}_{4}$ lifetime. Tm:CNGG crystals with optimized doping levels $(1-3$ at.\%) are very promising for ultra-broadband mid-IR laser sources.
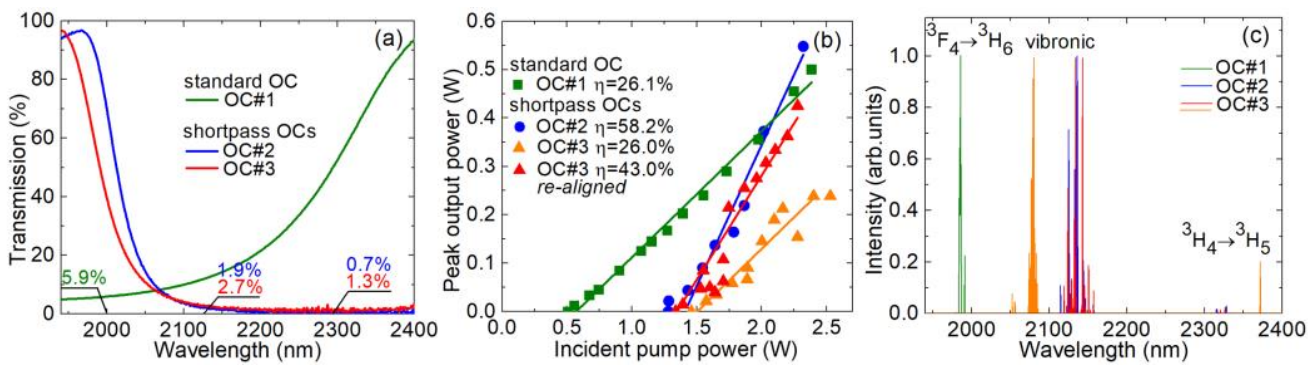

Fig. 2 Mid-infrared Tm:CNGG laser: (a) transmission spectra of the output couplers (OCs), values specify $T_{\mathrm{OC}}$ at $2 \mu \mathrm{m}, 2.13 \mu \mathrm{m}$ and $2.3 \mu \mathrm{m}$; (b) input-output dependences, $\eta$-slope efficiency; (c) typical spectra of laser emission.

\section{References}

[1] Z. Pan, Y. Wang, Y. Zhao, H. Yuan, X. Dai, H. Cai, J. E. Bae, S. Y. Choi, F. Rotermund, X. Mateos, J. M. Serres, P. Loiko, U. Griebner, and V. Petrov, "Generation of 84-fs pulses from a mode-locked Tm:CNNGG disordered garnet crystal laser," Photon. Res. 6(8), 800-804 (2018).

[2] P. Loiko, E. Kifle, L. Guillemot, J.-L. Doualan, F. Starecki, A. Braud, M. Aguiló, F. Díaz, V. Petrov, X. Mateos, and P. Camy, "Highly efficient $2.3 \mu \mathrm{m}$ thulium lasers based on a high-phonon-energy crystal: evidence of vibronic-assisted emissions," J. Opt. Soc. Am. B 38(2), 482-495 (2021). 